\begin{tabular}{|l|l|l||}
\hline \multicolumn{2}{|c|}{ PublisherInfo } \\
\hline \hline PublisherName & $:$ & BioMed Central \\
\hline \hline PublisherLocation & $:$ & London \\
\hline \hline PublisherImprintName & $:$ & BioMed Central \\
\hline \hline
\end{tabular}

\title{
Mitochondrial proteomics
}

\begin{tabular}{|l|l|l||}
\hline \multicolumn{2}{|c|}{ ArticleInfo } \\
\hline \hline ArticleID & $:$ & 3827 \\
\hline \hline ArticleDOI & $:$ & $10.1186 /$ gb-spotlight-20001113-01 \\
\hline \hline ArticleCitationID & $:$ & spotlight-20001113-01 \\
\hline \hline ArticleSequenceNumber & $:$ & 264 \\
\hline \hline ArticleCategory & $:$ & Research news \\
\hline ArticleFirstPage & $:$ & 1 \\
\hline \hline ArticleLastPage & $:$ & 2 \\
\hline \hline & & RegistrationDate : 2000-11-13 \\
ArticleHistory & $:$ & OnlineDate \\
\hline \hline ArticleCopyright & $:$ & BioMed Central Ltd2000-11-13 \\
\hline \hline ArticleGrants & $:$ & \\
\hline \hline ArticleContext & $:$ & 130591111 \\
\hline \hline
\end{tabular}




\section{Jonathan B Weitzman}

Email: jonathanweitzman@hotmail.com

The production of ATP in the mitochondria requires protein synthesis and the cooperation of a large number of mitochondrial ribosomal proteins (MRP), over 50 of which have already been identified in yeast. In the 20th October Journal of Biological Chemistry Koc et al. used a range of proteomics tools to identify and classify novel mammalian MRPs (J Biol Chem 2000, 275:32585-32591). Small-subunit ribosomal proteins were isolated and separated using two-dimensional polyacrylamide gel electrophoresis, followed by in-gel tryptic digests, capillary liquid chromatography and electrospray tandem mass spectrometry. The protein sequence data were combined with 'cyberprobing' of various genomes and analysis using the MitoProt databases. Of the six mammalian MRP identified, only two have clear prokaryote homologs (E. coli S10 and S14). Homologs of the other four human MRPs were found in flies, worms, mice and yeast. These results pave the road to the identification of the 30-or-so proteins that make up the small subunit of the mammalian mitochondrial ribosome.

\section{References}

1. Mitochondrial ribosomal proteins (MRPs) of yeast.

2. Journal of Biological Chemistry, [http://www.jbc.org]

3. Mitochondria Project, [http://www.mips.biochem.mpg.de/proj/medgen/mitop]

This PDF file was created after publication. 